\title{
A camerate crinoid from the Upper Silurian (Ludlow) Moydart Formation of Nova Scotia, Canada
}

\author{
Stephen K. Donovan ${ }^{1}$ and Ron K. Pickerill 2 \\ IDepartment of Geology, University of the West Indies, Mona, Kingston 7, Jamaica \\ ${ }^{2}$ Department of Geology, University of New Brunswick, Fredericton, New Brunswick E3B 5A3, Canada
}

Date Received April 13, 1995

Date Accepted August 4, 1995

\begin{abstract}
Well-preserved fossil echinoderms are uncommon in the Arisaig Group (early Silurian to early Devonian) of Nova Scotia. Although not preserving sufficient detail to enable specific identification, a crinoid, monobathrid camerate gen. et sp. indet. from the Moydart Formation (late Silurian, late Ludlow), shows the following features: a long, heteromorphic (N212) column of circular section and with convex nodals; a broad, conical dorsal cup with broad, high radials; fixed, uniserial arms which branch twice; 20 long, free arms that are uniserial most proximally, but are otherwise biserial; and numerous, elongate, blade-like pinnules. The column of this species differentiates it from a second taxon commonly preserved perpendicular to bedding in the Moydart Formation. Thus, while one species in this formation is preserved autochthonously in life position, another forms a crinoid lagerstätte and coquinas of more complete specimens, but is, at best, parautochthonous.
\end{abstract}

Les échinodermes fossiles bien conservés sont rares dans le Groupe d'Arisaig (Silurien inférieur au Dévonien inférieur) de la Nouvelle-Écosse. Bien qu'il n'ait pas conservé suffisamment de détails pour permettre une identification précise, un crinoïde à chambres monobathride de genre et espèce indéterminés provenant de la Formation Moydart (Silurien supérieur, Ludlow supérieur) présente ces caractéristiques : longue colonne hétéromorphe (N212) d'une section circulaire avec nodales convexes; vaste calice dorsal conique avec rayons endosquelettiques élevés et étendus, et bras unisériés à deux niveaux de ramifications; 20 longs bras libres qui sont unisériés proximalement, mais qui sont bisériés plus loin; ainsi que maintes pinnules oblongues en fer de lance. La colonne de cette espèce la différencie d'un deuxième taxon ordinairement conservé perpendiculairement au litage dans la Formation Moydart. Ainsi, même si une espèce de cette formation est conservée de façon autochtone dans une position vitale, une autre peut être formée de lagerstătte crinoïdes et de coquillages cunéiformes de spécimens plus complets, mais, au mieux, subautochtones.

[Traduit par la rédaction]

\section{INTRODUCTION}

The Arisaig Group of Nova Scotia is a 1400 to $1500 \mathrm{~m}$ thick, essentially marine siliciclastic, platformal sequence ranging in age from earliest Silurian to early Devonian. Despite the international importance of the biostratigraphic and palaeoecologic database provided by this mid-Palaeozoic succession (Boucot et al., 1974; also see review in Donovan and Pickerill, 1995), certain aspects of the Arisaig Group are still poorly known. For example, the fossil echinoderms, generally recognised as an important component of Palaeozoic, shallow-marine environments, have received little attention in published accounts of the fauna. In his memoir on the Arisaig succession, McLean (1924) noted the occurrence of rare fossil asteroids assigned to Mesopalaeaster(?) parviusculus (Billings, 1860) and Urasterella ruthveni (Forbes, 1848) arisaigensis Ruedemann, 1916. Of the Arisaig asteroids, M.? parviusculus is based on the holotype only (Schuchert, 1915, p. 88) from the McAdam Brook Formation (late Silurian, early Ludlow), while $U$. ruthveni arisaigensis is known from two specimens from the Stonehouse Formation (late Silurian to early Devonian, Pridoli to Lochkovian). The only other de- tailed discussion of fossil echinoderms from this succession was by Donovan and Pickerill (1995), who described and interpreted crinoid columns preserved in life position in the informally named green member of the Moydart Formation (late Silurian, late Ludlow; Fig. 1). The present communication describes the first 'complete' fossil crinoids from the Moydart Formation; specimens were obtained from a single horizon in the green member that preserves multiple specimens of a large, 20-armed monobathrid camerate.

Crinoid terminology follows Webster (1974), Moore et al. (1978) and Ubaghs (1978). The higher classification of crinoids used herein follows Simms and Sevastopulo (1993). For practical reasons the naming of plate circlets in the dorsal cup follows the traditional orientation determined by the arms (Ubaghs, 1978), rather than the revised system of Simms (1994) that refers to the orientation of the column. Described specimens are deposited in the Division of Natural Sciences, New Brunswick Museum, Saint John, New Brunswick (NBMG). 


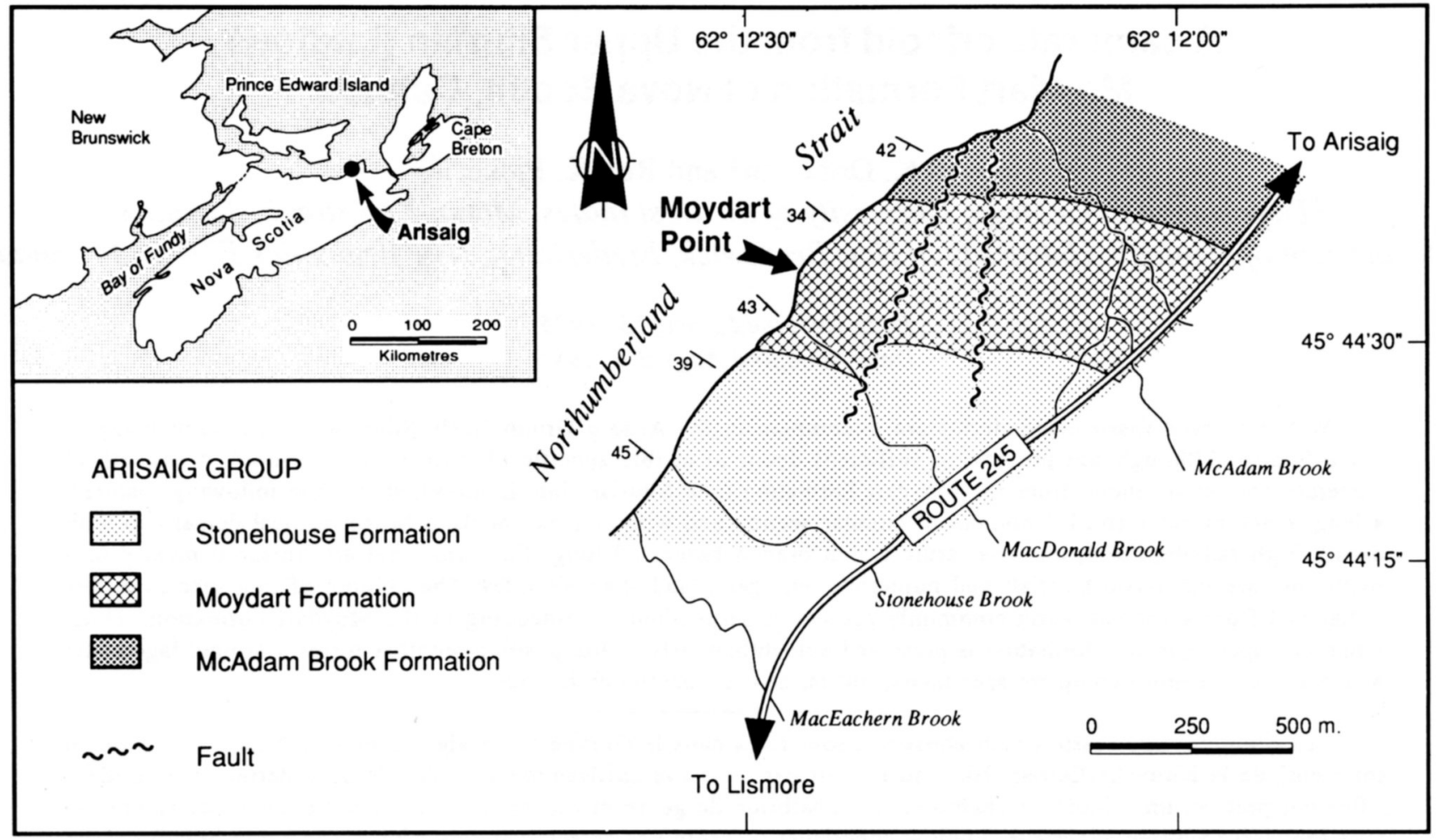

Fig. 1. Geologic map of the succession of the Arisaig Group in the area adjacent to Moydart Point (after Donovan and Pickerill, 1995, fig. 1). The specimens discussed herein were collected from the green member of the Moydart Formation (the red member occurs at the top of the formation). The inset map shows the position of Arisaig in eastern Canada.

\section{Systematic PALAEONTOLOGY \\ Class Crinoidea Miller, 1821}

Subclass Camerate Wachsmuth and Springer, 1885

Order Monobathrida Moore and Laudon, 1943

Monobathrid camerate gen. et sp. indet.

Figures 2 to 4

Crinoid crown; Tansathien, 1992, plate 4.8.

20-armed camerate crinoid; Donovan and Pickerill, 1995

\section{Material}

The following specimens were collected: a crown, preserving the free arms only, NBMG 9942a, b (Figs. 2, 3.1-3.3); a large, partial theca, preserving part of the dorsal cup, NBMG 9943 (Figs. 2 [left of centre], 3.4); two fragments of a theca, preserving part of the fixed arms, NBMG 9944a, b (Fig. 4); and various fragments of pluricolumnal, NBMG 9945. NBMG 9944a, b were collected from coquinal horizons; all other specimens come from the horizon illustrated in Figure 2. Other specimens (such as the crown right of centre in Fig. 2) were left in the field, being too difficult to collect.

\section{Locality and horizon}

NBMG 9942, 9943 and 9945 are from a single bed, a crinoid lagerstătte (Donovan, 1991, p. 259), with well-preserved crinoids (Fig. 2) in the stratotype of the green member, Moydart Formation, Arisaig Group, located on the southern shore of Northumberland Strait, northeastern main- land Nova Scotia, eastern Canada, approximately $4 \mathrm{~km}$ southwest of the small fishing village of Arisaig and $35 \mathrm{~m}$ northnortheast of MacDonald Brook (Fig. 1). For a detailed discussion of the stratigraphy and palaeoenvironment of the green member, Moydart Formation, see Tansathien (1992), Donovan and Pickerill (1995), and references therein. NBMG 9944a, b come from coquinas within the local succession. It is perhaps relevant to note that the next coquina beneath the crinoid lagerstätte includes fragments of camerate thecae, while the next higher coquina preserves crinoid arms.

\section{Description}

Stem: Attachment structure unknown. Articular facet of columnals circular in outline. Lumen small, central and pentagonal(?) in outline. Areola broad and circular. Articulation symplectial with a marginal crenularium of fine, unbranched or rarely branched, radial crenulae. Column heteromorphic, apparently N212 in lateral view, with some further intercalated internodals (for example, N2122) apparent only in ground section. Nodals tallest columnals in lateral view, with convex latera, but with strongly concave articular facets; priminternodals about as high or slightly higher than secundinternodals, with slightly convex latera; secundinternodals low and with planar latera. Latera unsculptured. Pluricolumnals generally straight, longest specimen seen in field $390+\mathrm{mm}$ and incomplete (Fig. 2, to left). One pluricolumnal preserved as an open planar spiral coil.

Theca: Theca elliptical in section (Fig. 3.1). Dorsal cup conical (Fig. 3.4) with a moderately broad stem facet of 


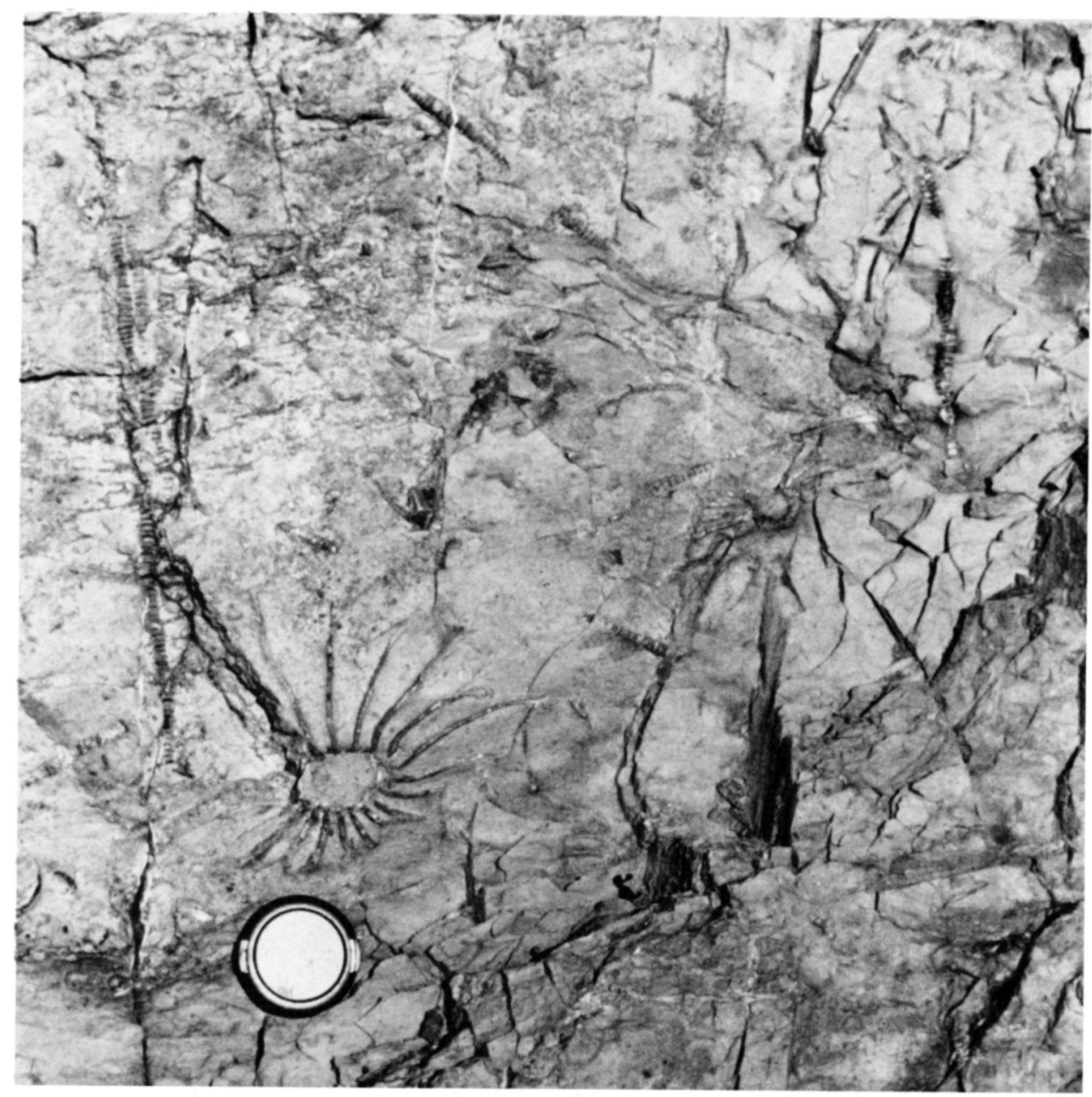

Fig. 2. Monobathrid camerate gen. et sp. indet., Moydart Formation, Arisaig Group; Upper Silurian (Ludlow). Field photograph of bedding plane assemblage of well-preserved crinoids in the crinoid lagerstätte. The collected crown (NBMG 9942 ) is just above the lens hood (compare with Fig. 3.1). Note a further, moderately well-preserved crown right of centre (a total of four specimens were noted showing this style of preservation), plus various pluricolumnals, particularly the long straight specimen to the left. Compare this view with Tansathien (1992, pl. 4.8). Lens hood diameter is $55 \mathrm{~mm}$.

rounded outline. Basal circlet moderately high. Exposed basal plate of NBMG 9943 apparently trapezoidal in outline and unsculptured. Radials higher than basals, broadly heptagonal in outline, higher than wide, narrowest at base, unsculptured, but with a weakly developed median ridge originating at about the centre of plate. First primibrachial(?) broad. Fragment of interprimibrachial plate(?) preserved just above radial:radial suture (Fig. 3.4).

Thecal fragments from coquinas (Fig. 4) preserve at least one of two episodes of isotomous branching in fixed arms, at primaxillary or, perhaps more probably, secundaxillary level. At least two further fixed brachials above axillary plate. Axillary and more distal brachials separated by hexagonal interbrachial plates (Fig. 4).

Arms: 20 free arms above calyx (Tansathien, 1992, pl. 4.8), indicating that each fixed arm branched twice isotomously. Fixed arms uniserial. Free arms slender, pinnulate and elongate. Free arms uniserial just above theca (Fig. 3.3, bottom left), becoming biserial more distally. Arms rounded rectangular in transverse section aborally, with long, planar sides and composed of low brachials (Fig. 3.3). Longest pre- served free arm about $85 \mathrm{~mm}$ long (at ' 12 o'clock' in Fig. 3.1) and incomplete. Pinnules numerous, elongate, blade-like, preserved either splayed out laterally (Fig. 3.2) or directed down into the sediment.

\section{Remarks}

Although the crown material of this species is well preserved, it is unfortunately incomplete, precluding a more precise taxonomic assignment. Nevertheless, taking into account the paucity of available information on the fossil echinoderms from the Arisaig Group, it is considered constructive to describe this taxon. In particular, the lack of a complete crown has prevented determination of the detailed plate arrangement of the theca. Such basic information as the number of plates in each of the basal and radial circlets is not available. Further, the thecal fragments collected from coquinas (Fig. 4) are not indisputably conspecific with the species found in the crinoid lagerstätte, although comparison of the available material suggests that associating these diverse specimens is not unreasonable. However, as other crinoid taxa do occur in this for- 


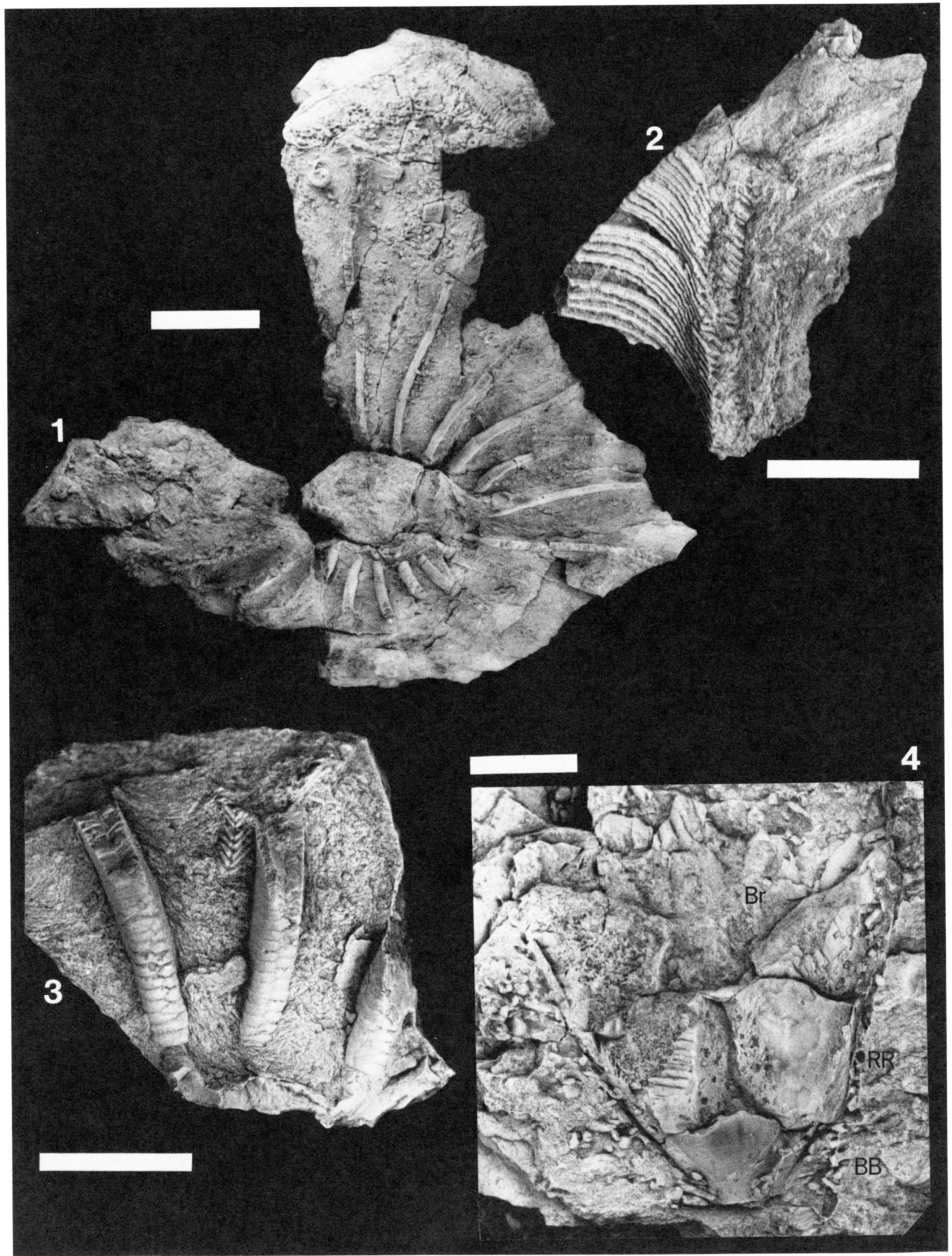




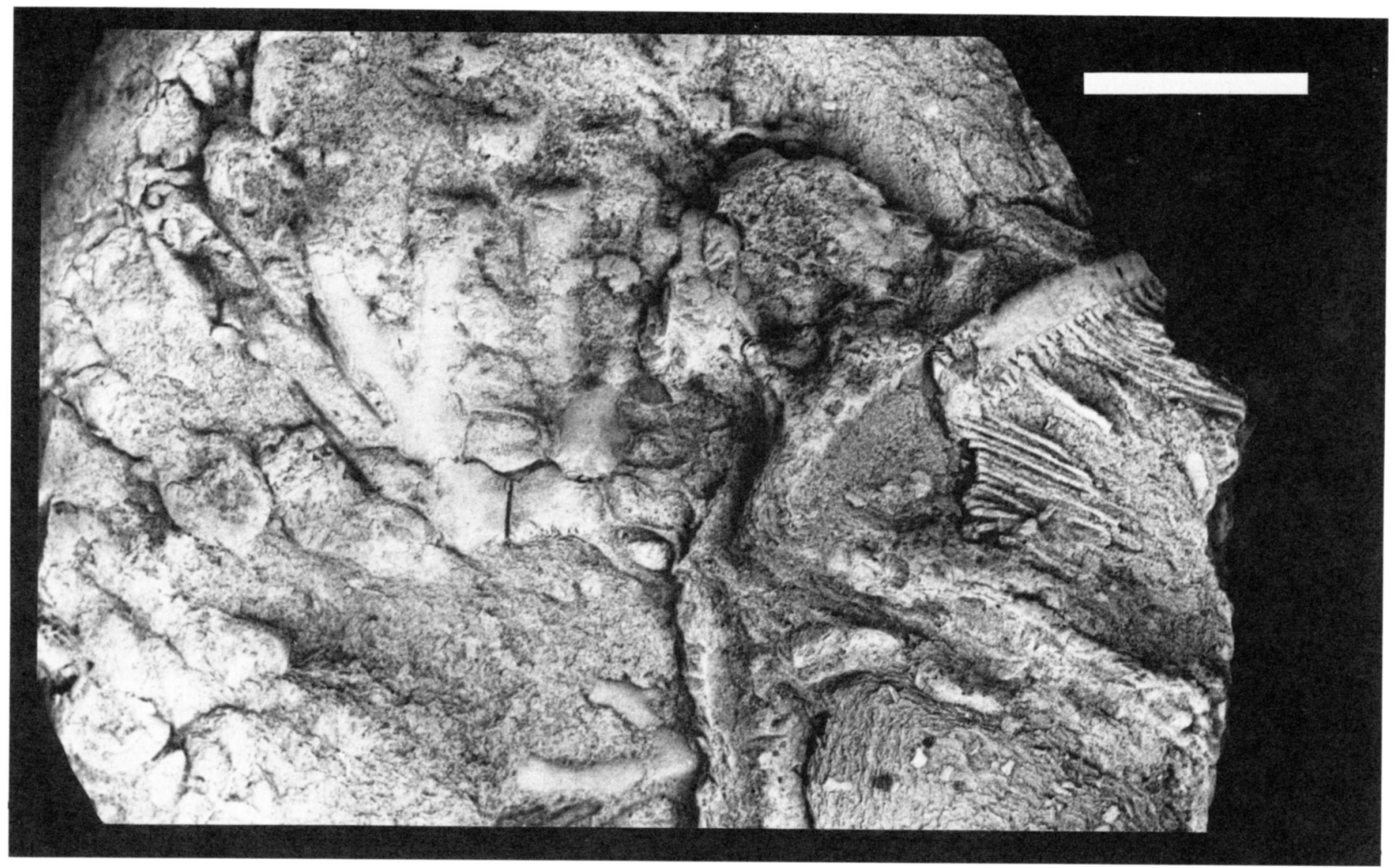

Fig. 4. Monobathrid camerate gen. et sp. indet., Moydart Formation, Arisaig Group; Upper Silurian (Ludlow), NBMG 9944a. Bedding surface of coquina, showing fragment of theca with branched, fixed arms (centre), a further thecal fragment (bottom centre; note V-shaped arm branch) and part of a pinnulate arm (right). Scale bar represents $10 \mathrm{~mm}$. Specimen painted with red food colouring and whitened with ammonium chloride sublimate before photography.

mation (Donovan and Pickerill, 1995; MacRae and Hall, 1995), it is conceded that the nature of the material could lead to errors in association. Despite these problems, features such as the large basal, radial and primibrachial plates, and the characters of the column and arms, suggest that this species may belong to the periechocrinacean compsocrinines or some morphologically similar group. In this context it is relevant to note that MacRae and Hall (1995) have recently recorded (albeit in abstract form only) the occurrence of the periechocrinacean compsocrinine Periechocrinus schultzianus (Angelin, 1878), associated with the pisocrinid disparid Cicerocrinus elegans Sollas, 1900, in the Moydart Formation. Regrettably, the holotype of $P$. schultzianus has been lost (R.A. MacRae, personal communication) and material regarded as conspecific awaits detailed description. Nevertheless, this brief record lends support to our tentative interpretation of the material described here as having periechocrinacean affinities.
The better preserved specimens in the crinoid bed are comprised of free arms radiating from a central elliptical area representing the position of the theca (Figs. 2, 3.1). However, the arms are preserved with the adoral groove directed into the sediment surface (Fig. 3.1, 3.3), indicating that the crown was toppled over, presumably from an originally elevated position, and is preserved resting on the adoral surface, which in life would be directed away from the substrate. This is similar to preservational scale II of Meyer et al. (1990: 'complete calyx, but no column attached'). Although the Moydart Formation specimens do not actually preserve the thecae and arms in close association, the crown and column do occur close together in the crinoid lagerstätte (for example, compare Fig. 2 herein with Meyer et al., 1990, fig. 2F); however, NBMG 9943 (Fig. 3.4) is a partial calyx with some plates articulated (preservational scale VI). These modes of preservation are suggestive of energetic burial of live specimens, particularly because delicate structures such as the pinnules (Fig. 3.2) are

Fig. 3. Monobathrid camerate gen. et sp. indet., Moydart Formation, Arisaig Group; Upper Silurian (Ludlow). (1, 3) NBMG 9942a. (1) Fixed arms radiating from position of theca (centre); the arms are preserved with the adoral groove orientated down into the sediment. Scale bar represents $30 \mathrm{~mm}$. (3) Details of three biserial arms. (2) NBMG $9942 \mathrm{~b}$. Details of pinnules (precise position on NBMG 9942a uncertain). (4) NBMG 9943. Lateral view of theca, showing basal (BB) and radial (RR) circlets, and the large first primibrachial $(\mathrm{Br})$. Scale bars represent $10 \mathrm{~mm}$ unless stated otherwise. All specimens painted with red food colouring and whitened with ammonium chloride sublimate before photography. 
retained. In contrast, the fragmented specimens in the coquinas (Fig. 4) possibly indicate energetic resedimentation of dead, partially disarticulated individuals, although occurrence of arm fragments bearing pinnules probably indicates the breakup of at least some living individuals (Donovan, 1991, pp. 254-257).

Worthwhile comparison can be made between the preservation of the monobathrid indet. and the upright, morphologically distinct pluricolumnals of the Moydart Formation (Donovan and Pickerill, 1995). The latter species has only been recognised perpendicular to bedding and is thus preserved in life position, that is, individuals are autochthonous. Crowns of this species are unknown and they presumably disarticulated above the sediment surface following death, so that only the part of the column buried during life was preserved. In contrast, the monobathrid indet. of the crinoid lagerstätte is more complete, but this is due to living individuals having been overwhelmed by, presumably, a mass flow event. Test fragments and bundles of pluricolumnals (Tansathien, 1992, pl. 4.7.1) of this species are found within coquinal deposits, which indicates preservation by energetic sedimentation. Therefore, while one species in the Moydart Formation is preserved autochthonously in life position, another forms a crinoid lagerstätte and coquinas of more complete specimens, but is, at best, parautochthonous.

The pluricolumnal (not collected) mentioned above, that is preserved as an open planar spiral coil, is perhaps suggestive of a distal attachment (=distal planar coil of Brett, 1981, table 1). However, it is more likely to be a coiled part of the column, indicating that it was highly flexible in life (Ausich and Baumiller, 1994).

\section{ACKNOWLedGements}

R.K.P. acknowledges the financial support provided by a grant from the Natural Sciences and Engineering Research Council of Canada. We thank R.A. MacRae for discussing his unpublished data. Constructive review comments by Jim Brower and Chris Paul are gratefully acknowledged.

Angelin, N.P. 1878. Iconographica crinoideorum in stratis Sueciae Siluricis fossilium. Samson and Wallin, Holmiae, 62 p.

Ausich, W.I. and Baumiller, T.K. 1994. Skeletal architecture and flexibility in crinoid stalks (Echinodermata). Geological Society of America, Abstracts with Programs, 26(7), p. A428.

Billings, E. 1860. Description of a new Palaeozoic starfish of the genus Palaeaster from Nova Scotia. Canadian Naturalist and Geologist, 5, pp. 69-70. [Not seen.]

Boucot, A.J., Dewey, J.F., Dineley, D.L., Fletcher, R., Fyson, W.K., Griffin, J.G., HickoX, C.F., McKerRow, W.S., and Ziegler, A.M. 1974. Geology of the Arisaig area, Antigonish County, Nova Scotia. Geological Society of America, Special Paper $139,191 \mathrm{p}$.

Brett, C.E. 1981. Terminology and functional morphology of attachment structures in pelmatozoan echinoderms. Lethaia, 14, pp. 343-370.

Donovan, S.K. 1991. The taphonomy of echinoderms: calcareous multi-element skeletons in the marine environment. In The processes of fossilization. Ediled by S.K. Donovan. Belhaven Press, London, pp. 241-269.

Donovan, S.K. and Pickerill, R.K. 1995. Crinoid columns pre- served in life position in the Silurian Arisaig Group of Nova Scotia, Canada. Palaios, 10, pp. 362-370.

Forbes, E. 1848. On the Asteriadae found fossil in British strata. Geological Survey of the United Kingdom, Memoir 2, pp. 457-482.

MACRAE, R.A. and Hall, R.L. 1995. Description and taphonomy of the crinoid Periechocrinus schultzianus (Angelin, 1878) from the Silurian Moydart Formation, Arisaig, Nova Scotia: a long time no sea. Geological Association of Canada/Mineralogical Association of Canada, Final Program and Abstracts, 20, p. A-64.

McLean, F.H. 1924. Palaeontology of the Silurian rocks of Arisaig, Nova Scotia. Geological Survey of Canada, Memoir 137, $180 \mathrm{p}$.

Meyer, D.L., Ausich, W.I., and Terry, R.E. 1990. Comparative taphonomy of echinoderms in carbonate facies: Fort Payne Formation (Lower Mississippian) of Kentucky and Tennessee. Palaios, 4 (for 1989), pp. 533-552.

MilLER, J.S. 1821. A natural history of the Crinoidea or lily-shaped animals, with observations on the genera Asteria, Eurayle, Comatula and Marsupites. Bryan and Company, Bristol, 150 p.

Moore, R.C. and LAUDon, L.R. 1943. Evolution and classification of Paleozoic crinoids. Geological Society of America, Special Paper 46, pp. 1-153.

Moore, R.C., Ubaghs, G., Breimer, A., and Lane, N.G. 1978. Glossary of crinoid morphological terms. In Treatise on Invertebrate Paleontology, Part T, Echinodermata 2(1). Edited by R.C. Moore and C. Teichert. Geological Society of America and University of Kansas Press, Boulder and Lawrence, pp. T229, T231, T233-T242.

Ruedeman, R. 1916. Account of some new or little known fossils, mostly from Palaeozoic rocks of New York. New York State Museum Bulletin, 189, pp. 7-97.

Schuchert, C. 1915. Revision of Paleozoic Stelleroidea with special reference to North American Asteroidea. U.S. National Museum Bulletin, 88, $311 \mathrm{p}$.

Simms, M.J. 1994. Reinterpretation of thecal plate homology and phylogeny in the Class Crinoidea. Lethaia, 26 (for 1993), pp. 303-312.

Simms, M.J. and Sevastopulo, G.D. 1993. The origin of articulate crinoids. Palaeontology, 36, pp. 91-109.

Sollas, W.J. 1900. Fossils in the Oxford University Museum. II. On two new genera and species of Crinoidea (Brahmacrinus ponderosus and Cicerocrinus elegans). Quarterly Journal of the Geological Society, 56, pp. 264-272.

TANSATHIEN, W. 1992. Benthic associations, ichnology and sedimentology of the Lower Silurian-Lower Devonian Arisaig Group, Nova Scotia. Unpublished M.Sc. thesis, University of New Brunswick, Fredericton.

UbaGhs, G. 1978. Skeletal morphology of fossil crinoids. In Treatise on Invertebrate Paleontology, Part T, Echinodermata 2(1). Edited by R.C. Moore and C. Teichert. Geological Society of America and University of Kansas Press, Boulder and Lawrence, pp. T58-T216.

WACHSMUTh, C. and SPRINGer, F. 1885. Revision of the Palaeocrinoidea, Part 3, Section 1. Discussion of the classification and relations of the brachiate crinoids, and conclusion of the generic descriptions. Proceedings of the Academy of Natural Sciences of Philadelphia for 1885, pp. 223-364.

Webster, G.D. 1974. Crinoid pluricolumnal noditaxis patterns. Journal of Paleontology, 48, pp. 1283-1288.

Editorial Responsibility: G.L. Williams 